\title{
Hydrolysis and hydrogenation of lipids in the rumen of goats
}

\author{
Yasukuni Watanabe, Tadashi Kyuma* and Hideo Mural \\ (Laboratory of Animal Physiology, Faculty of Agriculture, \\ Shinshu University, Ina, Japan) \\ (Received for Publication on April 11, 1969)
}

It has been recognized that the hydrolysis and hydrogenation processes of triglyceride and phospholipid occured in the rumen result from the activity of the rumen microorganisms. Although the fatty acids of pasture lipids are highly unsaturated, the lipid entering the small intestine increases saturated fatty acids. The hydrogenation of unsaturated fatty acids has been studied either by in vitro techniques ${ }^{12,13,14)}$, or by the analysis of rumen contents ${ }^{1,14)}$. Hydrolysis of lipid by rumen microorganisms was observed by GARTON et al. ${ }^{6)}$ and in vitro studies ${ }^{6,7)}$. These experiments showed that the unsaturated fatty acids were reduced when they were provided in triglyceride form in the rumen. BATH $e t a l .{ }^{1)}$ demonstrated by the method of duodenal re-entrance fistula that the hydrolysis and the hydrogenation of lipid occured rapidly in the rumen and lipid entering the duodenum consisted principally of saturation free fatty acids.

The experiments reported here are undertaken to make clear the processes of hydrolysis and hydrogenation of triglyceride in the rumen. The lipid and fatty acid composition of the rumen contents of goats were observed periodically during 24 hours following safflower oil feeding.

\section{Materials and Methods}

\section{Animals}

Two Saanen nanny goats were fitted with rumen fistulae. The live weight of goat $I$ and II were 26.5 and $33.5 \mathrm{~kg}$ respectively.

2. Experimental diets

The animals were housed indoors in individual pens and fed once daily at 9.00 a.m., $600 \mathrm{~g}$ orchard grass hay, $90 \mathrm{~g}$ ground soybean oil meal and $50 \mathrm{~g}$ safflower oil. The safflower oil was mixed thoroughly with the ground soybean oil meal. Oil was added to the hay in progressively larger amounts in 5 days. The animals were fed the experimental diet for at least 10 days before sampling of the rumen contents. Water and mineral mixture were provided ad libitum.

3. Extraction of lipid from rumen contents

Approximately $20 \mathrm{~g}$ of rumen contents were taken out periodically through the rumen fistula nine times during the period of 24 hours after feeding. Immediately after the sampling of rumen contents, lipids were extracted from the rumen contents by the methods of Folch et al. ${ }^{8}$

4. Fractionation and determination of lipids

The fractionations of lipids were performed quantitatively by the chromatographic separation on thin layers of silica gel (Wakogel B-O). N-hexan, ethyl ether and acetic acid (82: $18: 1 \mathrm{v} / \mathrm{v})$ were used to develop the chromatogram and the lipids were detected by spraying dichlorofluolescein and under ultraviolet lamp.

\footnotetext{
* Present address: Tohoku National Agricultural Experiment Station, Morioka.
} 
Hydrolysis and hydrogenation of lipids in rumen

Phospholipid was determined colorimetrically by the method of Harris and POPAT ${ }^{81}$. Glycerides and free fatty acids were determined by a modification of the microtitration method of PATTERSON ${ }^{11}$ involving saponification of the glycerides with ethanol and ethyl ether KOH. Cholesterol and cholesterol ester were determined colorimetrically by a modification of the method of $Z_{\mathrm{AK}}$ et al. ${ }^{16)}$

5. Separation and determination of fatty acids by gas-liquid chromatography

Lipid fractions for analysis by gas-liquid chromatography were obtained by elution from thin layer plates. Triglyceride, mono and di-glyceride, cholesterol and cholesterol ester were eluted with chloroform and phospholipid was eluted with methanol. Fatty acid methyl esters prepared by trans methylation with $0.5 \%$ sulfuric acid-methanol were analyzed by gas-liquid chromatography using twin column and flame ionization chromatograph (Shimadzu GC-1C). Chromatographic separation was done on $187 \mathrm{~cm}$ by $3 \mathrm{~mm}$ stainless steel columns packed with $20 \%$ diethylene glycol succinate polyester (DEGS) on 60-80 mesh celite. The columns were operated at a carrier gas (nitrogen) flow rate of $35 \mathrm{~m} / / \mathrm{min}$. and an oven temperature of $190^{\circ} \mathrm{C}$. The retention times of the unknowns were compared with a semilog plot of relative retention time versus carbon number prepared using mixtures of known standard esters. The proportion of each fatty acid methyl ester was determined by triangulation. The fatty acid patterns obtained were compared with published results ${ }^{11}$.

\section{Results}

Fatty acid composition of the diets: The fatty acid composition of the individual dietary component and the total daily intake of fatty acids are shown in Table 1. The orchard grass hay contained $3.7 \%$ of lipid and the fatty acid contents in extracted total lipid was $33 \%$. The safflower oil contained $77 \%$ of linoleic acid.

Lipid composition of rumen contents: The changes of lipid composition in the rumen of two goats after the feeding of safflower oil are shown in Table 2. The results obtained from those two goats showed similar values. The figures reported in Table 2 are mean values of two goats. It may be seen that a safflower oil feeding transitorily increased triglyceride only one hour after feeding and 3 hours later reduced to the level of before feeding. The proportion

Table 1. Composition and daily intake of fatty acids in the diets

\begin{tabular}{ccccc}
\hline Fatty acid* & \multicolumn{2}{c}{ Fatty acid composition } & $\begin{array}{c}\text { Total daily } \\
\text { intake }^{1}\end{array}$ \\
& Saffower oil & Hay & $(\mathrm{g})$ \\
16 & 0 & $(\%)$ & $(\%)$ & 5.3 \\
$16: 1$ & 9.3 & 16.9 & 0.4 \\
$18: 0$ & - & 6.8 & 1.7 \\
18 & 1 & 2.8 & 7.0 & 5.0 \\
$18: 2$ & 9.9 & 8.9 & 35.6 \\
$18: 3$ & 77.4 & 10.2 & 2.5 \\
Remainder & -10.0 & 0.9 \\
Total & 100.0 & 10.2 & 51.4 \\
\hline Total lipid & 100.0 & 100.0 & \\
in dry matter & & 3.7 & \\
\hline
\end{tabular}

* Carbon chain length: Number of double bonds.

1. $50 \mathrm{~g}$ safflower oil and $600 \mathrm{~g}$ hay were provided daily for goats.

2. Fatty acid contents in total lipid of hay was $33 \%$. 


\section{Watanabe $\cdot$ KYuma $\cdot$ Mural}

Table 2. Proportional change of lipids in the rumen contents after oil feeding

\begin{tabular}{|c|c|c|c|c|c|c|c|c|c|}
\hline \multirow{2}{*}{ Lipid class } & \multicolumn{9}{|c|}{ Time after feeding (hr) } \\
\hline & -1 & 1 & 3 & 6 & 9 & 12 & 16 & 20 & 24 \\
\hline & \multicolumn{9}{|c|}{$(\%)$} \\
\hline Triglyceride & 13.4 & 43.4 & 13.8 & 7.6 & 7.3 & 8.4 & 7.3 & 8.4 & 8.2 \\
\hline Free fatty acid & 62.3 & 34.5 & 60.3 & 70.0 & 70.5 & 6.5 & 71.1 & 69.4 & 71.6 \\
\hline Mono \& Di-glyceride & 8.8 & 11.0 & 12.7 & 7.9 & 10.7 & 11.0 & 10.3 & 10.1 & 8.1 \\
\hline Phospholipid & 12.2 & 9.6 & 10.9 & 12.3 & 9.5 & 12.1 & 10.0 & 10.0 & 10.3 \\
\hline Cholesterol & 3.1 & 1.4 & 2.1 & 2.0 & 1.7 & 1.9 & 1.3 & 2.0 & 1.7 \\
\hline Cholesterol ester & 0.3 & 0.2 & 0.2 & 0.2 & 0.2 & 0.1 & 0.1 & 0.1 & 0.2 \\
\hline
\end{tabular}

Table 3. Proportional change of fatty acid composition of triglyceride in the rumen contents after oil feeding

\begin{tabular}{|c|c|c|c|c|c|c|c|c|c|}
\hline \multirow{2}{*}{ Fatty acid } & \multicolumn{9}{|c|}{ Time after feeding (hr) } \\
\hline & -1 & 1 & 3 & 6 & 9 & 12 & 16 & 20 & 24 \\
\hline $12: 0$ & 1.5 & $\operatorname{Tr}$ & 0.3 & $0.7^{(}$ & 1.3 & 1.5 & 0.8 & 0.8 & 1.3 \\
\hline $13: 0$ & 2.5 & - & - & - & - & $\operatorname{Tr}$ & $\operatorname{Tr}$ & $\operatorname{Tr}$ & $\operatorname{Tr}$ \\
\hline $14: 0$ & 2.7 & 0.2 & 0.7 & 2.1 & 3.5 & 5.0 & 3.5 & 2.8 & 3.4 \\
\hline $14: 1$ & $\operatorname{Tr}$ & $\operatorname{Tr}$ & $\operatorname{Tr}$ & 0.2 & 0.4 & 1.6 & 0.6 & 0.5 & 1.4 \\
\hline $15: 0$ & 1.3 & $\operatorname{Tr}$ & 0.8 & 0.7 & 2.1 & 1.0 & 0.8 & 0.8 & 1.9 \\
\hline $16: 0$ & 11.7 & 9.4 & 11.7 & 17.0 & 22.8 & 21.6 & 20.2 & 17.8 & 19.6 \\
\hline $16: 1$ & 3.1 & 0.6 & 1.9 & 3.7 & 5.5 & 6.1 & 5.4 & 4.4 & 5.8 \\
\hline $18: 0$ & 16.4 & 3.4 & 5.0 & 8.0 & 10.9 & 12.2 & 14.1 & 11.4 & 11.7 \\
\hline $18: 1$ & 26.7 & 16.4 & 19.3 & 23.5 & 27.6 & 26.0 & 26.4 & 24.6 & 24.6 \\
\hline $18: 2$ & 19.3 & 68.9 & 56.9 & 35.1 & 13.4 & 15.3 & 16.0 & 17.4 & 15.4 \\
\hline $18: 3$ & 2.2 & 0.6 & 0.4 & 1.7 & 2.9 & 4.4 & 4.7 & 4.0 & 4.5 \\
\hline $20: 0$ & 0.7 & 0.5 & 0.5 & 0.7 & 0.9 & 0.6 & 2.2 & 0.6 & 0.9 \\
\hline Remainder & 11.9 & $\operatorname{Tr}$ & 2.5 & 6.6 & 8.7 & 4.7 & 5.3 & 14.9 & 9.5 \\
\hline
\end{tabular}

of free fatty acid in the rumen transitorily decreased with compensatory increase of triglyceride. The total sum of the proportion of triglyceride and free fatty acid remained almost constant during 24 hours of experimental periods. Mono and di-glyceride slightly increased 3 hours after oil feeding, but remained almost constant from 8 to $11 \%$ of total lipid during the experimental periods. The highest percentage of triglyceride and the lowest percentage of free fatty acid occured once at one hour after oil feeding. The mean percentage of free fatty acid in total lipids over 24 hour period was highest than the other lipids in the rumen. The percentage of phospholipid, cholesterol and cholesterol ester remained almost constant throughout 24 hours.

Fatty acid composition of triglyceride and free fatty acid in rumen contents: The means of the proportional changes of the fatty acid composition of triglyceride and free fatty acid in the rumen are given in Table 3 and 4. It is clear from the observed fatty acid composition, that the triglyceride in 1 to 3 hours after feeding consisted principally of unhydrolyzed safflower oil. One hour after oil feeding $69 \%$ linoleic acid was present, but this decreased rapidly in 6 hours to approximately constant level of 13 to $17 \%$. In the experiment of 24 hours duration the oleic acid in the triglyceride fraction reached the maximum at 9 hours after feeding and con- 
Hydrolysis and hydrogenation of lipids in rumen

tained $27 \%$ and then decreased slowly to approximately $25 \%$. The muximum percentage of stearic acid was observed at 16 hours after feeding. The relative proportions of the fatty acid compositions in the triglyceride fraction reduced during 1 to 6 hours after oil feeding except for linoleic acid. After 9 hours from the oil feeding the fatty acid composition of the triglyceride fraction did not vary appreciably.

The linoleic acid in free fatty acid fraction was always low and slightly increased during 1 to 3 hours after the oil feeding. One hour after oil feeding the proportion of oleic acid in the free fatty acid fraction was $33 \%$, but this increased rapidly at 6 hours and then decreased slowly to the level of before feeding in 24 hours. The percentage of stearic acid in the free

Table 4. Proportional change of fatty acid composition of free fatty acid in the rumen contents after oil feeding

\begin{tabular}{|c|c|c|c|c|c|c|c|c|c|}
\hline \multirow{2}{*}{ Fatty acid } & \multicolumn{9}{|c|}{ Time after feeding (hr) } \\
\hline & -1 & 1 & 3 & 6 & 9 & 12 & 16 & 20 & 24 \\
\hline & & & & ( & & & & & \\
\hline $12: 0$ & 0.1 & $\operatorname{Tr}$ & $\operatorname{Tr}$ & $\operatorname{Tr}$ & 0.1 & $\operatorname{Tr}$ & $\operatorname{Tr}$ & 0.1 & 0.1 \\
\hline 130 & - & - & - & - & - & - & - & - & - \\
\hline $14: 0$ & 0.3 & 0.4 & 0.3 & 0.6 & 0.4 & 0.4 & 0.6 & 0.5 & 0.4 \\
\hline $14: 1$ & 0.2 & 0.7 & 1.0 & 0.9 & 0.8 & 0.1 & 1.5 & 1.3 & 0.7 \\
\hline 150 & 0.4 & 0.4 & 0.4 & 0.7 & 0.6 & 0.7 & 0.7 & 0.8 & 0.7 \\
\hline $16: 0$ & 8.6 & 9.3 & 9.5 & 8.2 & 8.0 & 8.9 & 9.0 & 8.9 & 8.7 \\
\hline $16: 1$ & 0.3 & 0.7 & 0.6 & 0.9 & 0.4 & 0.2 & 0.4 & 0.5 & 0.3 \\
\hline $18: 0$ & 54.3 & 44.3 & 32.4 & 32.6 & 41.0 & 48.2 & 47.3 & 46.8 & 50.5 \\
\hline $18: 1$ & 30.9 & 33.2 & 43.0 & 49.5 & 43.2 & 37.5 & 36.1 & 34.9 & 32.4 \\
\hline $18: 2$ & 0.6 & 5.3 & 4.9 & 1.1 & 0.6 & $\mathrm{Tr}$ & 0.5 & 0.6 & 0.4 \\
\hline $18: 3$ & 0.7 & 0.5 & 0.6 & 0.5 & 0.6 & 0.4 & 0.6 & 0.7 & 1.3 \\
\hline $19: 0$ & 1.1 & 0.9 & 0.7 & 1.4 & 1.2 & 0.9 & 1.0 & 1.5 & 1.1 \\
\hline Remainder & 2.4 & 4. 4 & 6.7 & 3.8 & 3.1 & 2.5 & 2.2 & 3.5 & 3.4 \\
\hline
\end{tabular}

Table 5. Proportional change of fatty acid composition of mono and di-glyceride in the rumen contents after oil feeding

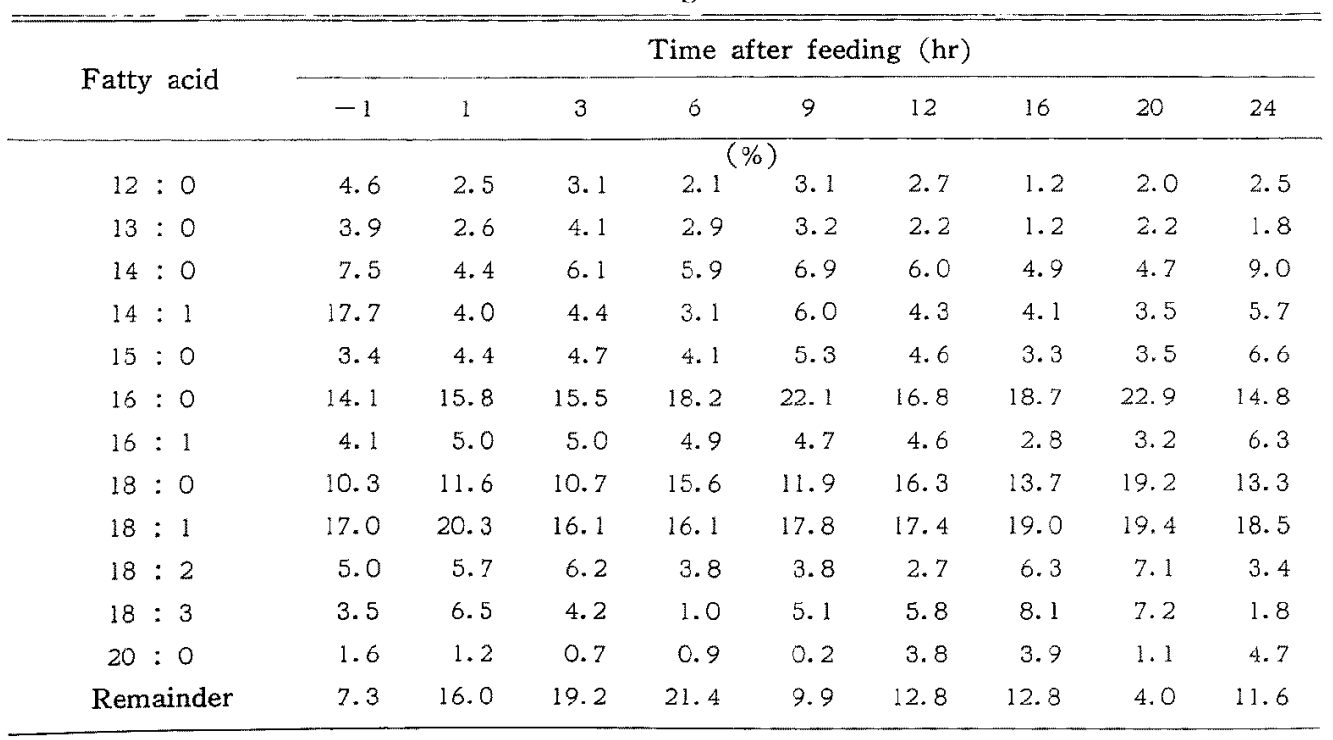


Table 6. Proportional change of fatty acid composition of phospholipid in the rumen contents after oil feeding

\begin{tabular}{crrrrrrrrrr}
\hline & \multicolumn{7}{c}{ Time after feeding (hr) } \\
\cline { 2 - 10 } Fatty acid & \multicolumn{1}{c}{-1} & \multicolumn{1}{c}{ 1 } & \multicolumn{1}{c}{3} & \multicolumn{1}{c}{6} & 9 & 12 & 16 & 20 & 24 \\
\hline $12: 0$ & 2.6 & 1.8 & 1.6 & 2.6 & 2.6 & 2.5 & 3.8 & 2.9 & 3.3 \\
$13: 0$ & 2.9 & 3.3 & 2.4 & 3.1 & 3.4 & 3.3 & 4.1 & 2.7 & 3.4 \\
$14: 0$ & 5.8 & 6.3 & 5.1 & 7.9 & 9.3 & 7.5 & 11.2 & 8.3 & 7.2 \\
$14: 1$ & 8.4 & 7.6 & 5.8 & 6.6 & 7.5 & 8.9 & 10.3 & 8.3 & 8.3 \\
$15: 0$ & 6.8 & 6.2 & 4.1 & 3.5 & 4.1 & 6.3 & 5.6 & 5.0 & 5.8 \\
$16: 0$ & 26.2 & 23.1 & 21.1 & 19.8 & 16.1 & 21.1 & 14.0 & 16.2 & 19.8 \\
$16: 1$ & 4.4 & 4.9 & 4.6 & 4.5 & 4.1 & 4.1 & 3.9 & 4.5 & 5.2 \\
$18: 0$ & 10.4 & 7.4 & 11.6 & 10.0 & 8.3 & 6.3 & 4.7 & 5.3 & 5.6 \\
$18: 1$ & 11.1 & 10.8 & 18.4 & 17.0 & 13.3 & 11.7 & 8.7 & 10.9 & 9.6 \\
$18: 2$ & 3.1 & 7.9 & 5.7 & 4.3 & 4.1 & 4.1 & 4.3 & 3.6 & 5.0 \\
$18: 3$ & 3.3 & 3.3 & 3.3 & 3.3 & 3.7 & 2.9 & 5.0 & 6.7 & 4.3 \\
Remainder & 15.0 & 17.4 & 16.3 & 17.4 & 13.5 & 20.8 & 24.4 & 25.6 & 22.5 \\
\hline
\end{tabular}

fatty acid fraction reached the maximum at 12 hours after feeding and remained constant during the remainder of the 24 hours. The fatty acids of the free fatty acid fraction with exception of $\mathrm{C}_{18}$ fatty acids did not vary appreciably throughout the 24 hours.

Fatty acid composition of mono and di-glyceride and phospholipid in rumen contents: The fatty acid composition of the mono and di-glyceride fraction of the rumen contents (Table 5) did not vary appreciably with time after oil feeding. The fatty acid compositions of mono and di-glyceride fraction were differed markedly from those of triglyceride and free fatty acid fraction; of particular note was unable to demonstrate the increase of $\mathrm{C}_{\mathbf{1 8}}$ fatty acids after oil feeding. Short chain and odd carbon number fatty acids were observed more quantity in the mono and di-glyceride fraction than the triglyceride and free fatty acid fraction.

The fatty acid composition of the phospholipid fraction of the rumen contents (Table 6) was characterized by a low proportion of stearic acid and a high proportion of short chain and odd carbon number fatty acids. In the experiment of 24 hours duration there was a transitory increase of linoleic and oleic acid in the phospholipid fraction, correspond with the increase of these fatty acids in the free fatty acid fraction in the rumen.

\section{Discussion}

The results obtained ndicated that the rapid hydrolysis of the triglyceride occured during 3 hours after oil feeding. In the experiment of 24 hour duration, the proportion of triglyceride decreased rapidly in short period and there was a corresponding increase in the proportion of free fatty acids. Appreciable changes of the proportion of the mono and di-glyceride could not be observed in the rumen after oil feeding. These results obtained suggest that the rapid and complete hydrolysis of triglyceride and production of free fatty acids occured in the rumen during the first 3 hours after feeding. BATH and HILL ${ }^{1)}$ demonstrated that the hydrolysis of lipid occured very rapidly in the rumen and also they observed 68 to $87 \%$ of free fatty acids in the total lipid.

GARTON et al. ${ }^{77}$ failed to detect mono or di-glyceride during the in vitro fermentation of 
linseed oil by rumen microorganisms. BATH and $\mathrm{HrLL}^{1 /)}$ reported the virtual absence of mono and di-glyceride in rumen contents with the exception of dietary origin. However, HAwKE and ROBERTSON ${ }^{9 /}$ observed $13 \%$ di-glyceride and $27.3 \%$ mono-glyceride in the total lipid of bovine rumen contents. Throughout the experimental period of 24 hours after oil feeding mono and di-glyceride were detected appreciably in the rumen and were relatively constant proportion from 8 to $12 \%$ in total lipid. The results obtained suggest that the mono and di-glyceride fraction of lipid in the rumen originated from the microorganism body lipid, and if formed in the rumen by the partial hydrolysis of triglyceride that the mono and di-glyceride must have only a transient existence.

Furthermore, these assumptions were confirmed from the fatty acid composition of mono and di-glyceride fraction. The fatty acid composition of the mono and di-glyceride fraction differed markedly from that of the free fatty acid fraction in the lipid of rumen contents. Namely, the relative proportions of the individual fatty acids in the mono and di-glyceride fraction of rumen contents remained almost constant during experimental periods, and contained short chain and odd carbon number fatty acids. Furthermore, the results observed in gas-liquid chromatography of fatty acids of mono and di-glyceride fraction have many unidentified peaks which are considered to be higher and branched chain fatty acids or fatty aldehyde.

The processes of the hydrogenation to the unsaturated fatty acids could occur simultaneously with the hydrolysis of the triglyceride in the rumen. HAwKE and RoBERTsON ${ }^{9}$ demonstrated that the hydrogenation of unsaturated fatty acids occured more readily after the fatty acids have been liberated by hydrolysis than when they are present in triglyceride. The results obtained tend to confirm the observation of НАWKE $e t$ al., i.e. the hydrolysis of the triglyceride occured more rapidly than the hydrogenation of unsaturated fatty acids in the rumen. The fact that there was a more rapid increase of oleic acid than that of stearic acid in the free fatty acid fraction in response to feeding safflower oil indicated that the hydrogenation of dienoic acid was more rapid than that of monoenoic acid.

The fatty acid composition of phospholipid fraction differed markedly from that of the free fatty acid fraction. It has been demonstrated that the linoleic or linolenic acid could not be detected in the phospholipid of rumen microorganisms ${ }^{4)}$. However, KEENEY $e t a l .^{10}$ and ERWIN et $a l .{ }^{2}{ }^{2}$ reported the presence and synthesis of linoleic acid by rumen microorganisms. A comparison of the fatty acid composition of the phospholipid fraction between rumen microorganisms $^{10)}$ and rumen contents ${ }^{1)}$ would tend to confirm that the phospholipid is of microorganism body lipid origin. The results obtained suggest that the incorporation of $\mathrm{C}_{18}$ unsaturated fatty acids into the phospholipid of rumen microorganism body lipid occured by a large dose of linoleic acid in the rumen. These assumptions were confirmed from the changes of the linoleic and oleic acid in the phospholipid fraction at various time after feeding.

Wood et al. ${ }^{15)}$ demonstrated that the slight degradation and absorption of long chain free fatty acids occured in the rumen. However, the proportional change of lipid fraction did not occur appreciably with exception for the hydrolysis of triglyceride and production of free fatty acids in the rumen. The results obtained suggest that the absorption of long chain fatty acids could not occur appreciably through the rumen epithelium.

\section{Summary}

The lipid fraction and the fatty acid composition of individual lipid fraction of the rumen 


\section{Watanabe - KYUMa - MURat}

contents of goats observed periodically during 24 hours after feeding on diets containing safflower oil have been studied. The results obtained were summarized as follows;

1. Hydrolysis of triglyceride occured very rapidly in the rumen and free fatty acid increased correspondingly. Phospholipid and mono, di-glyceride accounted for 9-12 and 8-11\% of total lipid respectively during 24 hours in the rumen.

2. The linoleic acid in free fatty acid fraction was always low, but oleic acid increased rapidly at 6 hours after feeding and then decreased more slowly to the level of before feeding. The stearic acid in free fatty acid fraction reached the maximum at 12 hours after feeding and remained constant during remainder of the 24 hours. Hydrolysis of triglyceride occured more rapidly than the hydrogenation of unsaturated fatty acids in triglyceride fraction.

3. The fatty acid composition of mono and di-glyceride fraction did not vary during 24 hours after safflower oil feeding. It is suggested that the partial hydrolysis of triglyceride and accumulation of mono and di-glyceride could not occur in the rumen. It appears probable that the mono and di-glyceride were originated from microbial body lipid.

4. There was a transitory increase of linoleic and oleic acid in the phospholipid fraction correspond with the increase of these fatty acids in free fatty acid fraction in the rumen. It is suggested that unsaturated fatty acids are incorporated into microbial body phospholipid.

\section{References}

1) BATh, I.H. and K.J. Hill (1967) J. Agr. Sci., Camb. 68: 139-148.

2) Erwin, E.S., W. Sterner and G.J. Marco (1963) J. Am. Oil Chem. Soc., 40: 344-347.

3) Folch, J., M. Lees and G.H. Sloan Stanley (1957) J. Biol. Chem., 226: 497-509.

4) Garton, G.A. and A.E. Oxford (1955) J. Sci. Fd. Agric., 6: 142-148.

5) Garton, G.A., P.N. Hobson and A.K. Lovgh (1958) Nature, Lond. 182: 1511-1512.

6) Garton, G.A., A.K. Lough and E. Vioque (1959) Biochem. J., 73: 46 p.

7) Garton, G.A., A.K. Lough and E. Vioque (1961) J. gen. Microbiol., 25: 215-225.

8) Harris, W.D. and P. Popat (1954) J. Am. Oil Chem. Soc., 31: 124-127.

9) Hawke, J.C. and J.A. Robertson (1964) J. Sci. Fd. Agric., 15: 283-289.

10) Keeney, M., I. Katz and M.J. Allison (1962) J. Am. Oil Chem. Soc,, 39: 198-201.

11) Patterson, D.S.P. (1963) Res. Vet. Sci., 4: 230-237.

12) Shorland, F.B., R.O. WEenik and A.T. Johns (1955) Nature, Lond. 175: 1129-1130.

13) Shorland, F.B., R.O. Weenik, A.T. Johns and I.R.C. McDonald (1957) Biochem. J., 67: $328-333$.

14) WARd, P.F.V., T.W. ScotT and R.M.C. Dawson (1964) Biochem. J., 92: 60-68.

15) Wood, R.D., M.C. Bell, R.B. Graigner and R.A. Teekell (1963) J. Nutr., 76: 62-68.

16) ZAK, B., D.A. Luz and M. Fisher (1957) Am. J. of Med. Tech., 23: 283-287. 


\title{
やぎの第一胃内における脂質の加水分解と水素添加
}

\author{
渡辺泰邦・久馬忠* 村井秀夫
}

(信州大学農学部)

反虫動物の第一霄内において，給与脂兾は第一胃内微 生物によって加水分解定うけ，また不館和脂肪酸は水素 添加されて飽和脂肪酸となることが認められている，こ のような第一胃内においての脂質のうける变化の過程を 明確にするために，不飽和脂肪酸としてのリノール酸を 多量に含さトリグリセりド老給与した場合の，第一胃内 に斿ける脂質各分画とその脂肪酸組成の経時变化を，飼 料給与後 24 時間にわたって検案した。

やぎ 2 頭定実験に用い, 乾草と大豆粕を基礎飼料とし， リノール酸含量が $77 \%$ のフラワー油学 $50 \mathrm{~g}$ 加えて实 験飼料とした。実験飼料給与後， 24 時間に的たって 9 回，第一胃フィステルより第一鼠内容を採取して総脂質 を抽出した。抽出総脂質は薄層タロマトダラフ法によっ てトリグリセリド，壬拉よびディグリセリド，FFA， リン脂筫，コレステロールおよびコレステロールエステ ル飞分画して，てれぞれ定量した．各脂貿分画について その脂肪酸組成索がスクロマトグシフ法によって定量し た。 その結果は次のように要的される。

1. 第一胃内においてトリグリセりドは等わ妨て短時 間内に加水分解学引ける。このために第一胃内にはFFA がもっと多く存在した。またもノおよびディグリセり

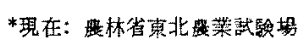

ドが常に 9-10\% 存在してほ上んど経時変化がなが た、りン脂質，コレステロール常にほぼ一定嫼が存在 Lた.

2. FFA 分画にはオレイン酸が給与挠 6 時間にすみ やかに增加し，以後やや隇少した。ステアリン酸が 12 時 閵後まで徐々に增加し，以後その量它保った。リノール 酸はFFA 分画に 6 時䦚以後妵とえど存在せず，遊踓し た脂肪酸はただちに水素添加をうけることが䈍められ た.トリグリセりド分画の脂肪酸組成は採食 9 㭙間以後 はほぼ一定の組成定示し，トリグリセリドへの水素添加 は比較的少なく，またその脂肪酸組成より9時闍以後の トリダリセリドには菌体脂貿の存在が推察される。

3.モノ就よ゙ディグり七りドの脂肪酸組成は，サフ ラワー油の給与によっても一定の变化はなく、トリダリ セリドの部分水解によるこれらの蓄穔壮註とんどないと 考察される。常時 $10 \%$ 前後存在するモ/技よびディグ リセリドは菌体脂質に由来するものであることが推定さ れる。

4. リン脂質は己の脂肪酸組成上り主として菌体脂質 であることが考えられる。リノ一ル酸お上びオレイン酸

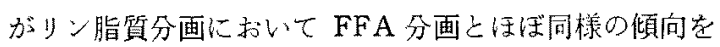
示すことより，これらの菌体リン脂質へのとりこ双が推 定される。 